\title{
SIMULATION OF OIL SPILLS NEAR A TROPICAL ISLAND IN THE EQUATORIAL SOUTHWEST ATLANTIC
}

\author{
Syumara QUEIROZ ${ }^{1 *}$; Laila FAZEKAS ${ }^{1}$; Marcus A. SILVA ${ }^{1}$; Moacyr ARAUJO ${ }^{1}$
}

\begin{abstract}
1 Laboratório de Oceanografia Física Estuarina e Costeira, Departamento de Oceanografia da Universidade Federal de Pernambuco - LOFEC/DOCEAN/UFPE, Av. Arquitetura s/n, 50740-550, Cidade Universitária, Recife, PE, Brazil. E-mail: syumaraqueiroz@hotmail.com, lailafazekas@gmail.com, marcus@ufpe.br, moa.ufpe@gmail.com

*Autor correspondente
\end{abstract}

RESUMO. Neste trabalho acoplamos o Sistema de Modelagem Oceânica - modelo de Circulação Oceânica Regional ROMS com o modelo de dispersão de óleo MEDSLIK-II para simular a evolução de derramamentos acidentais de petróleo de petroleiros que viajam próximo ao Arquipélago de Fernando de Noronha no Atlântico Sudoeste tropical. Seis cenários foram avaliados, consistindo de três pontos de derrame no lado leste do Arquipélago em dois meses (março e julho). Os resultados mostram que a predominância de forçantes advectivas tenderia a se sobrepor aos processos de degradação do óleo e encurtar a janela de tempo para possíveis ações de mitigação. O pior cenário ocorreu em março com a pluma atingindo a ilha dentro de $48 \mathrm{~h}$ com $2,25 \%$ do volume inicial (1350 tonnes) aderido na costa. A região atingida faz parte da área do Parque Nacional Marinho de Fernando de Noronha. Nós propomos a delimitação de uma região entre $3^{\circ} 41.9^{\prime} \mathrm{S}$ e $03^{\circ} 57^{\prime} \mathrm{S}$ e $\sim 62 \mathrm{~km}$ perpendicular ao limite leste da FNA, restritiva ao tráfego de petroleiros para aumentar a janela de resposta no caso de um derrame de óleo.

Palavras-Chave: Modelo semi-lagrangeano, ROMS, MEDSLIK-II, Arquipélago de Fernando de Noronha, Intemperismo do óleo.

\begin{abstract}
In this work we coupled the Ocean Modelling System - ROMS Regional Oceanic Circulation model with the MEDSLIK-II hydrocarbon dispersion model to simulate the evolution of accidental oil spills from tankers that travel near the Fernando de Noronha Archipelago in the tropical Southwest Atlantic. Six scenarios were evaluated, consisting of three spill positions on the eastern side of the Archipelago and two months (March and July). The results show that the predominance of advective forcings would tend to counteract the oil degradation processes and shorten the time window for possible mitigation actions. The worst scenario occurred in March with the plume reaching the island within 48 hours with $2.3 \%$ of the initial volume (1350 tonnes) adhering to the shore. The affected region is part of the Fernando de Noronha Marine National Park area. We propose the delimitation of a region between $3^{\circ} 41.9^{\prime} \mathrm{S}$ and $03^{\circ} 57^{\prime} \mathrm{S}$ and $\sim 62 \mathrm{~km}$ perpendicular from the eastern limit of the FNA, restrictive to tanker traffic to increase the time window response in case of an oil spill.
\end{abstract}

Keywords: Semi-lagrangian model, ROMS, MEDSLIK-II, Fernando de Noronha Archipelago, Oil wheathering. 


\section{INTRODUCTION}

Oceanic islands are considered hotspots of biodiversity and host a large amount of endemic species. Additionally, their isolation makes them a repository of threatened species as priorities regions for legal conservation acts (Gillespie, 2007; Gove et al., 2016; Whittaker and FernándezPalacios, 2007). Despite located in overall oligotrophic waters, the banks and islands off North/Northestern region of Brazil present expressive fishery activity (Hazin, 1993). Biological productivity in this region is influenced by the dynamic of the hydrographic conditions, which are mainly attributed to the interaction between topography and flow. Such 'island-effect' is considered to enhance nutrients availability in sub-superficial waters, increasing the primary productivity in Fernando de Noronha Archipelago (hereafter, FNA), Rocas Atoll and São-Pedro São Paulo islands (Becker, 2001; Chaves et al., 2006; Ekau and Knoppers, 1999; Leitao et al., 1999; de Souza et al., 2013; Souza, 2004; Travassos et al., 1999).

Among Brazilian oceanic islands, FNA is the best studied and has the largest number of species, both marine and terrestrial, a fact attributed to its extension and the heterogeneity of its habitats. FNA has the status of Conservation Unit allowing the protection of endemic species and the maintenance of a healthy island ecosystem (Serafini and França, 2010). Regardless of the recent protection status, since its occupation FNA has been submitted to several changes on the natural characteristics of its terrestrial and marine ecosystems. Currently the island ecosystems suffers with anthropic pressure from tourism activities, which is the main economic activity of FNA, as well as the introduction of exotic species (Serafini and França, 2010; Silva Jr, 2003; Soto, 2006, 2009). Additionally, contaminants released offshore may reach the protected area. The beach records of virgin pellets from oceanic sources are examples of the exposure of these islands (Do Sul et al., 2009). Another potential risk for oceanic islands is the occurrence of offshore oil spills from cargo and tanker ships. The high number of vessels, including oil tankers, circulating around the globe concomitantly with the increase of extreme events as storms, tropical cyclones due to climatic change increases the probability of oil spills (Cruz and Krausmann, 2013). The lack of infrastructure and mitigation plans at FNA could increase the impact when facing an oil spill scenario.

The major forcing contributing for the oil transport in aquatic environments are wind - shear and stokes drift as a function of the wind speed - and surface currents (Spaulding, 2017). In addition to transport, oil spill impact depends mainly on the environmental conditions that controls the weathering processes at the site of the spill (currents, climate, waves, etc.) and the time required to engage mitigation operations (Lee et al., 2015; Marta-Almeida et al., 2013; NRC, 2003). Weathering is a general definition for changes in oil properties due to physical, chemical and biological processes when the spill is exposed to environmental conditions such as in aquatic systems. The main weathering processes occurs on the surface (spreading, evaporation, 
photodegradation and emulsification), in the water column (dissolution, dispersion, adsorption to particulate matter, biodegradation) and the sediment (biodegradation) (Fig. 1).

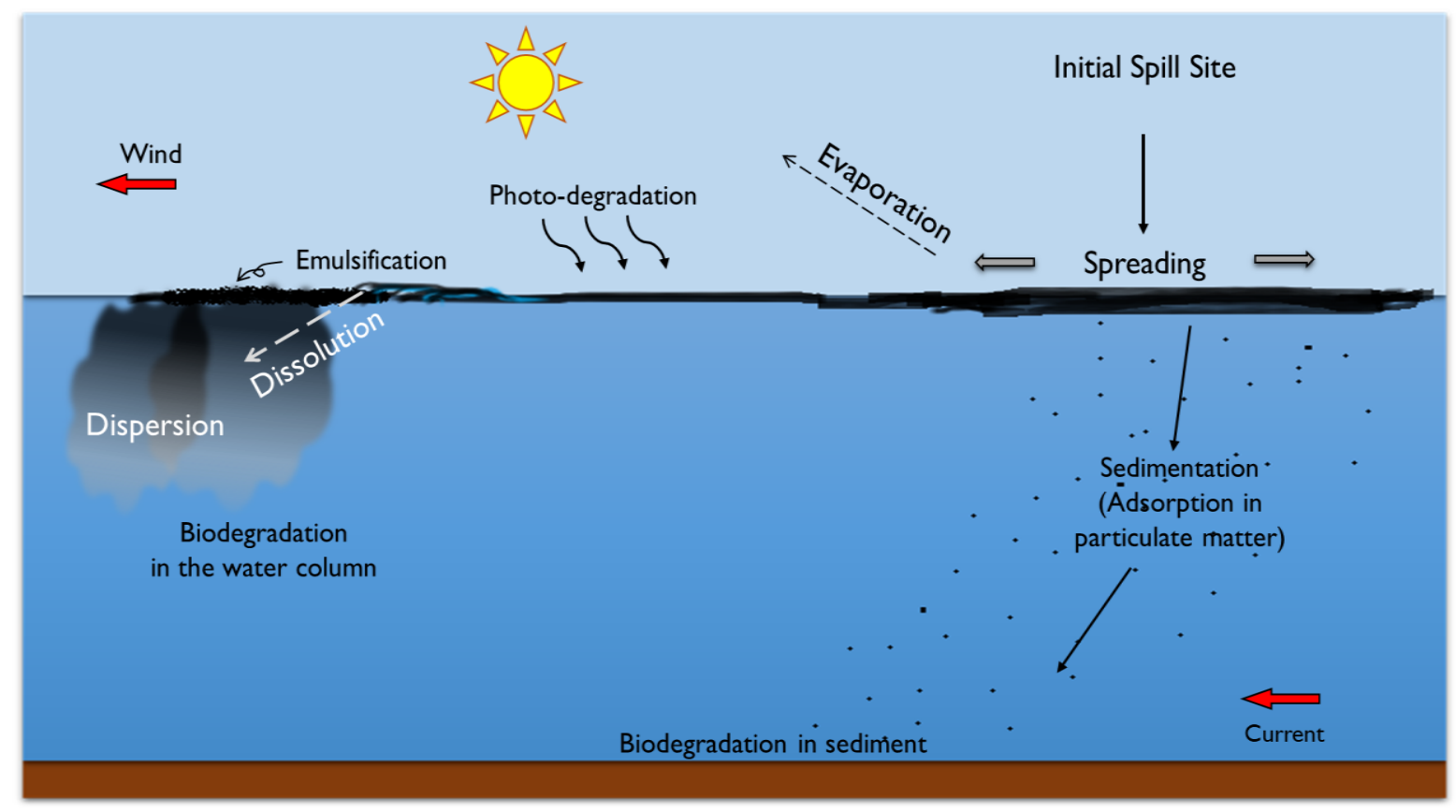

Figure 1. Major weathering processes acting on an oil spill.

The sustainable management of coastal zones should benefit from the implementation of systems with accurate operational oceanographic systems enabling the prediction of oil trajectories after the initial spill, such as modelling systems (Lee et al., 2015). The results of model spill scenarios accounting for the weathering increases effectiveness in accident prevention and containment so that the mitigating measures provided for by law can be implemented (Wang et al., 2005). The principal weathering processes that are incorporated into oil spill models are the spreading, evaporation, emulsification, dissolution, dispersion, sedimentation and biodegradation (Spaulding, 2017).

Most of the works studying oil spills in tropical regions consider the weathering after the oil has already reached the coast (e.g. Oudot and Dutrieux, 1989; Page et al., 1979). However, the plume behavior and weathering before reaching the coast may alter significantly the remaining oil proprieties (Lee et al., 2015). Indeed, the effects of these processes to the containment and mitigation effectiveness is recognized as one of the key factors to better prepare to an oil spill incident (Nordvik, 1999).

Here we implemented a semi-lagrangian ROMS/MEDSLIK-II coupled model to simulate oil spills based on the position of real ship tankers tracks near FNA. The coupled model ROMS/MEDSLIK-II incorporates the Regional Ocean Modelling System - ROMS (Shchepetkin and 
McWilliams, 2003, 2005) with the MEDSLIK-II model (De Dominicis et al., 2013a,b). This coupling allows integrating ROMS ocean circulation results, compatible with the low latitude dynamics, with a Lagrangian MEDSLIK-II oil model that considers the transport and weathering processes (evaporation, spreading, dispersion, emulsification and coastal adhesion) that act on the spill (De Dominicis et al., 2013a,b).

\section{MATERIAL AND METHODS}

\section{STUDY AREA}

The Fernando de Noronha Archipelago (FNA) is located between latitudes $03^{\circ} 45^{\prime} \mathrm{S}$ and $03^{\circ} 57^{\prime} \mathrm{S}$ and longitudes $32^{\circ} 19^{\prime} \mathrm{W}$ and $32^{\circ} 41^{\prime} \mathrm{W}$ (Fig. 2), in the Western Equatorial South Atlantic. It is composed of 21 islands and islets, with a total area of $26 \mathrm{~km}^{2}$ (IBAMA, 2005). Two Federal Conservation Units (UCs) are located in the archipelago: the Fernando de Noronha Marine National Park - PARNAMAR/FN (BRASIL, 1988) and the Fernando de Noronha Environmental Protection Area - APA/FN (BRASIL, 1986).

The climate in the region is warm tropical with an average air temperature of $25^{\circ} \mathrm{C}$ and welldefined dry season between August and February and rainy season between March and July, with an average annual rainfall of $1400 \mathrm{~mm}$ (Serafini and França, 2010). The maximum average insolation occurs in the month of November and the minimum in April (IBAMA, 2005). The seasonal signal is mostly modulated by the Intertropical Tropical Convergence Zone (ITCZ), which reaches its southern most position between February and March and northern most position in August (Lumpkin and Garzoli, 2005; Stramma and Schott, 1999). The prevailing winds are the southeast trade winds, with greater intensities between July and August (Tchamabi et al., 2017). The highest sea surface temperatures (SST) occurs between March and June, with values exceeding $28^{\circ} \mathrm{C}$, due the occurrence of the southwestern tropical Atlantic warm pool (Cintra et al., 2015), and the lowest between August and November, (SST $26.5^{\circ} \mathrm{C}$ ) (Hounsou-Gbo et al., 2015; Silva et al., 2009; Tchamabi et al., 2017).

In surface, the central branch of the South Equatorial Current (cSEC) flows westward until it reaches the North Brazil Current (NBC) near the coast (Lumpkin and Garzoli, 2005; Stramma and Schott, 1999). Te cSEC is stronger between March and July and weaker between August and February (Lumpkin and Johnson, 2013; Tchamabi et al., 2017). 


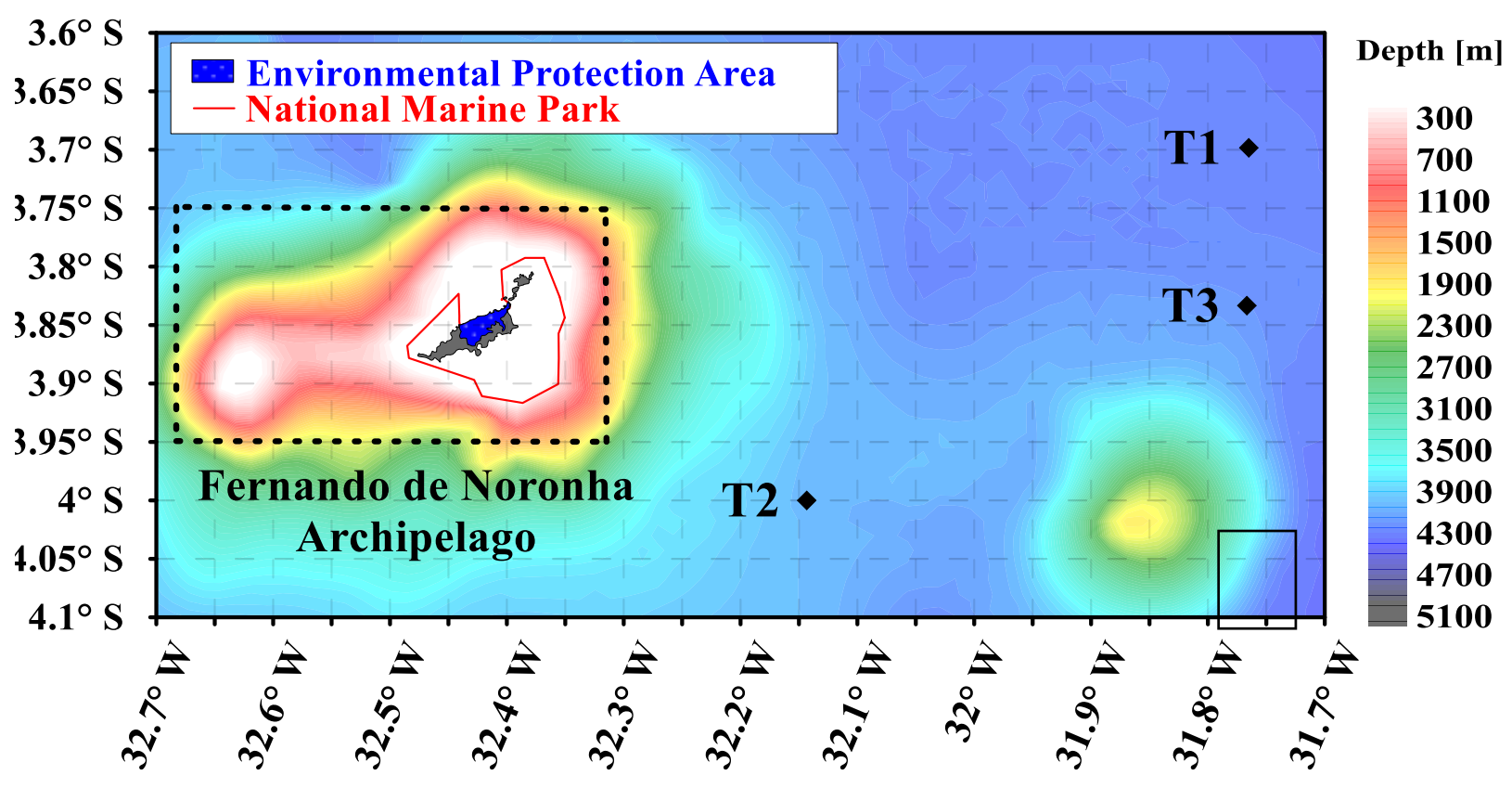

Figure 2. Location of the Fernando de Noronha Archipelago (FNA) (black dashed line). The area delimited in red corresponds to the Marine National Park (PARNAMAR) and in blue to the Environmental Protection Area (APA) of Fernando de Noronha. T1, T2 and T3 show the coordinates of three release oil spill scenarios considered in simulations.

\section{ROMS/MEDSLIK-II COUPLED MODEL}

ROMS is a three-dimensional, free-surface, numerical oceanic model that solves NavierStokes' primitive equations on a rotating Earth, considering Boussinesq's approach and hydrostatic equilibrium. In this model, the pressure gradients are solved in a barotropic-baroclinic coupled system that recovers processes lost or altered by rigid lid assumption (Shchepetkin and McWilliams, 2003, 2005). For the coupling we used the version ROMS_AGRIF/ROMSTOOLS developed by the French Institute of Research for Development - IRD (French Institut de Recherche pour le Développement) (Penven et al., 2008).

The configuration of the ROMS model for the simulation of circulation was based on the applied and validated by Tchamabi et al. (2017). The computational domain of the model consisted of the limits of the mesh between $3^{\circ} \mathrm{S}-5^{\circ} 10^{\prime} \mathrm{S}$ and $35^{\circ} \mathrm{W}-31^{\circ} \mathrm{W}$ (Supp. 1 ) with horizontal and vertical resolution of $1 / 70^{\circ}(\sim 1.5 \mathrm{~km})$ and 40 sigma levels, respectively. Stretching parameters were chosen in order to increase the resolution at the surface and bottom as $\theta \_s=6$ and $\theta \_b=0.6$ (Song and Haidvogel, 1994). Bathymetry was obtained from the Navy Hydrographic Center (CHM) merged with data from the GEBCO (Global Earth Bathymetric Chart of the Oceans, http://www.gebco.net/) database with a resolution of 0.5 ', with smoothing after interpolation.

The advective scheme corresponded to RSUP3 (Lemarié et al., 2012; Marchesiello et al., 2009). We adopted the non-local scheme of planetary layer K-profile-parameterization for vertical 
mixing to for unresolved processes of scale below the grid (Large et al., 1994). The surface forcings were the input of heat and freshwater flow from the Comprehensive Ocean-Atmosphere Data Set (COADS) with monthly average fields with grid intervals at each $0.5^{\circ}$ (Da Silva et al., 1994). Wind shear was derived from the monthly NASA Quick Scatterometer (QuiksCAT) climatology, known as SCOW (Scatterometter Climatology of Ocean Winds) with grid resolution ranges of $0.25^{\circ}$ (Risien and Chelton, 2008). Horizontal boundary conditions have been opened at all 4 borders. To improve the numerical solution, high resolution $(9.28 \mathrm{~km})$ TSM data from Advanced Very High Resolution Radiometer (AVHRR) - Pathfinder were used to calculate the heat flow (Casey and Cornillon, 1999). The model was initiated and forced with the temperature and salinity distributions extracted from the monthly climatology of the World Ocean Atlas 2013 (WOA), and the initial speeds determined by geostrophy. The simulations were integrated for 10 years spin-up with a minimum time step of 4 minutes and the average output every 2 days.

MEDSLIK-II is a Lagrangean oil model that can be coupled with ocean circulation models to solve the problems of transport, diffusion and transformation of oil on the sea surface. In MEDSLIK-II, the oil spill is represented by the state variables called "spill", "particle" and "structural". The spill type state variables are used to solve the variation in oil concentration due to weathering processes (evaporation, spreading, dispersion, emulsification and coastal adhesion) acting on the total volume of oil. These processes are presented as empirical relationships between the volume of the spill, the wind at 10 meters (W) and the SST. Next, the spill is divided in $\mathrm{N}$ particles of defined volume and the state variables "particle" are defined to solve advectivediffusive processes and for the subsequent calculation of the concentration at the surface, water column and coast (structural type variables) (De Dominicis et al., 2013a,b).

For coupling the ROMS to MEDSLIK-II (Fig. 3), subroutines have been created in the source code and some secondary MEDSLIK-II codes (medslik_II.sh, Extract_II.for and medslik_II.for). These new routines are necessary to recognize the ROMS output files (in netCDF format) as forcing input (SST, currents and winds) for MEDSLIK-II. As additional information the Supplementary 1 presents the flowchart with the MEDSLIK-II operating scheme and the files to which the new subroutines have been added (in red). Thus, we use the results from ROMS simulation as forcing for the MEDSLIK-II. 
Inicial conditions:

Temperature and salinity distribution and initial geostrophic velocities

\section{Forcings:}

Heat Flux, freshwater inputs and wind data

\section{Other parameters}

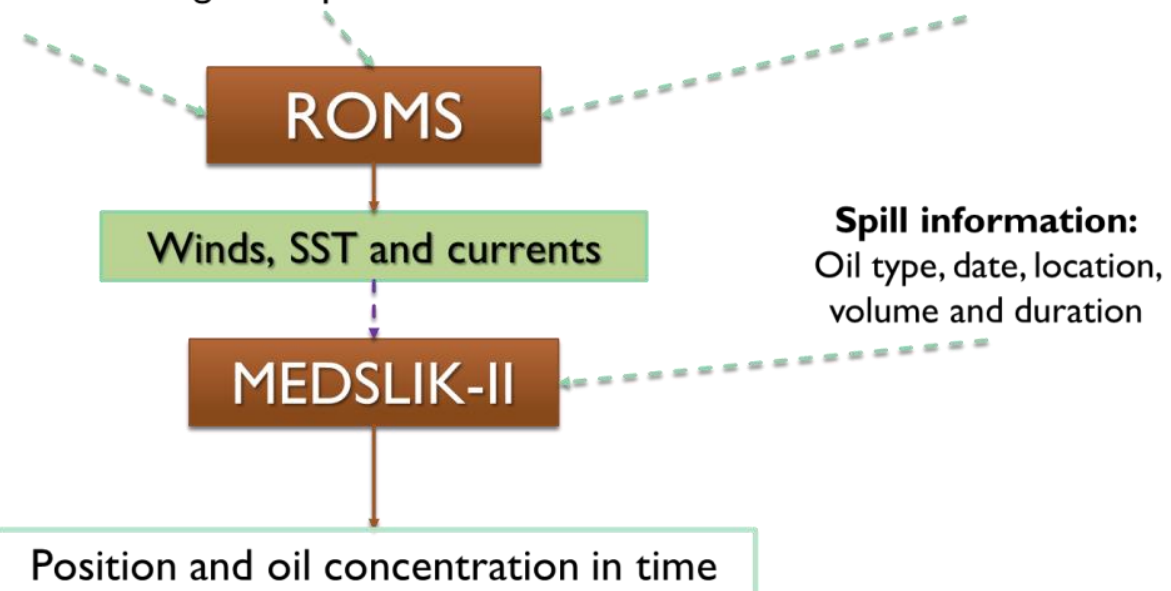

Figure 3. Simplified scheme of the coupled models ROMS and MEDSLIK-II with the inputs (dashed arrow) and outputs (filled arrow) for ROMS and MEDSLIK-II modes.

\section{SIMULATION SCENARIOS}

The monthly averaged currents and winds for March and July for the simulation served as forcings for the MEDSLIK-II simulations. The choice of these two periods allows analysing the highest risk scenario since March and July correspond, respectively, to the start of the cSEC intensification (with a lower wind intensity) and the period of higher intensity of the cSEC (with the increase of the southeast trade winds intensity) (Lumpkin and Garzoli, 2005; Molinari, 1982). For the MEDSLIK-II run three initial spill releasing points were determined - T1 $\left(3^{\circ} 41.9^{\prime} S\right.$; $\left.31^{\circ} 45.9^{\prime} \mathrm{W}\right)$, T2 (4०00.0'S; $\left.32^{\circ} 08.6^{\prime} \mathrm{W}\right)$ and T3 $\left(3^{\circ} 50.0^{\prime} \mathrm{S} ; 31^{\circ} 46.0^{\prime} \mathrm{W}\right.$ ) on the east side of Fernando de Noronha Island (see Fig. 2). This results in a total of six scenarios evaluated (two seasons and three releasing points), with hourly departures and figures every 6 hours, from the start of the spill to 48 hours. These releasing points were chosen based on the minimum distance positions from the archipelago of the main vessel tracks registered in the Marine Traffic website (MARINETRAFFIC, 2017). Only spill positions on the eastern side of FDA were accounted considering the dominant westward direction of the wind (SE trades) the surface current (cSEC).

The instantaneous volume of spilled oil was defined as 60,000 tonnes, which corresponds to half the capacity of Transpetro's Suezmax ship, of $26^{\circ} \mathrm{API}$ (intermediary oil type) which is the most used ship in the Brazilian oil and gas exploratory activities (ANP, 2017). All MEDSLIK-II parameters and constants for oil weathering were used according to the standard values (De Dominicis et al., 2013b) with the Stokes drift activated as recommended by De Dominicis et al. (2013a). 


\section{RESULTS}

The wind velocity used as forcing in ROMS was $4.66 \mathrm{~m} . \mathrm{s}^{-1}\left( \pm 0.14 \mathrm{~m} . \mathrm{s}^{-1}\right)$ and $7.08 \mathrm{~m} . \mathrm{s}^{-1}$ $\left( \pm 0.14{\left.\mathrm{~m} . \mathrm{s}^{-1}\right)}\right.$ in March and July, respectively (Fig 4a,b). SST was higher in March than in July, with mean values of $28.26^{\circ} \mathrm{C}\left( \pm 0.10^{\circ} \mathrm{C}\right)$ and $26.85^{\circ} \mathrm{C}\left( \pm 0.09^{\circ} \mathrm{C}\right)$, respectively (Fig. $\left.4 \mathrm{c}, \mathrm{d}\right)$. The mean surface current intensity varied from $0.39 \mathrm{~m} . \mathrm{s}^{-1}\left( \pm 0.06 \mathrm{~m} . \mathrm{s}^{-1}\right)$ with predominance of the zonal component in March to $0.34 \mathrm{~m} . \mathrm{s}^{-1}\left( \pm 0.04 \mathrm{~m} . \mathrm{s}^{-1}\right)$ in July, with a small deviation to the northeast (Fig. 4c,d). The oil transport was predominantly westward mainly due to the surface current direction. The influence of the wind seasonality increases the deviation to southwest in July, when the wind is stronger.
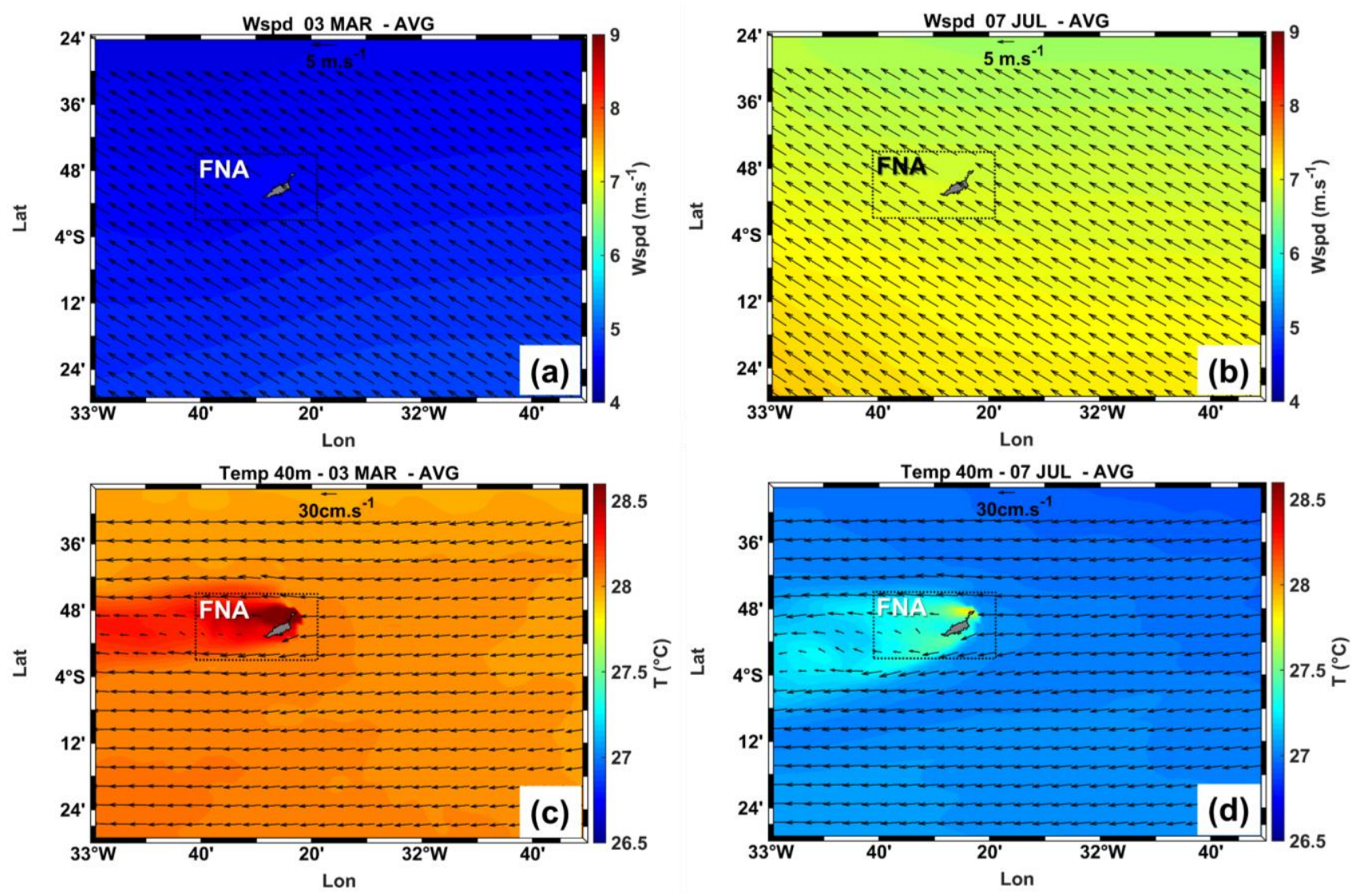

Figure 4. Wind intensity (colors, $\mathrm{m} . \mathrm{s}^{-1}$ ) and direction (arrows) for (a) March and (b) July; Sea Surface Temperature (colors, ${ }^{\circ} \mathrm{C}$ ) and surface current (arrows) for (c) March and (d) July.

The results for the oil concentrations (tonne. $\mathrm{km}^{-2}$ ) of the scenario T1 March (Supp. 3a-d) and July (Supp. 3e-h) are presented $12 \mathrm{~h}, 24 \mathrm{~h}, 36 \mathrm{~h}$ and $48 \mathrm{~h}$ after the spill. After half an hour from the start of the T1 spill, the percentage of evaporated oil in March and July was $1.9 \%$ and $2.5 \%$, respectively. After 1.5 hours, $24.5 \%$ of the oil volume was evaporated for both periods, which corresponds to the maximum percentage of the evaporative fraction of the spill defined in the model by the oil type. After 48 hours, $75.2 \%$ and $75.0 \%$ of the spillage remained on the surface 
in March and July, respectively. This small difference was due to the higher percentage of dispersed particles in the water column at the end of the simulation in July $(0.5 \%)$ when compared to March $(0.3 \%)$. In March, the emulsion formed after 30 minutes, suffered an increase in viscosity from $58.4 \mathrm{~m}^{2} \mathrm{~s}^{-1}$ to $2466.5 \mathrm{~m}^{2} \mathrm{~s}^{-1}$, without stabilization after 48 hours. In July, the initial viscosity of the emulsion was $79.5 \mathrm{~m}^{2} \mathrm{~s}^{-1}$ (30 min) with increase and stabilization at 31 hours to $2668.2 \mathrm{~m}^{2} \mathrm{~s}^{-1}$. In both T1 scenarios the spill did not reach the FN coast, however the deviation of the plume northward in relation to the island was greater in March than July. Nonetheless, the plume was within the area of the Fernando de Noronha Archipelago in July scenario at 48 hours (Fig. 5h).

The oil concentrations (tonne. $\mathrm{km}^{-2}$ ) of the T2 spill scenario in March (a-d) and July (e-h) are presented in Supp.4 for $12 \mathrm{~h}(\mathrm{a}, \mathrm{e}), 24 \mathrm{~h}(\mathrm{~b}, \mathrm{f}), 36 \mathrm{~h}(\mathrm{c}, \mathrm{g})$ and $48(\mathrm{~d}, \mathrm{~h})$ hours after the spill. For T2 the percentage evaporated after 30 minutes was $1.9 \%$ for March and $2.5 \%$ for July. The maximum evaporative percentage of the spill (24.5\%) was reached after 1.5 hours for March and 1 hour for July. The percentage of surface oil volume at the end of the T2 simulation was $75.2 \%$ and $75.0 \%$, with the final dispersed percentage of $0.3 \%$ and $0.6 \%$ in March and July, respectively. The viscosity of the emulsion formed at 30 minutes was $58.8 \mathrm{~m}^{2} \mathrm{~s}^{-1}$ and $79.8 \mathrm{~m}^{2} \mathrm{~s}^{-1}$ in March and July, respectively. The viscosity of the emulsion was stabilized after 19 hours in July (at $2662.5 \mathrm{~m}^{2} \mathrm{~s}^{-1}$ ) and did not stabilize in the March scenario (2463.8 $\mathrm{m}^{2} \mathrm{~s}^{-1}$ after 48 hours). As in the T1 scenario, in the T2 scenario the spill did not reach the FN coast, with the difference residing in the deviation of the spill to the south of the island and out of the domain after 39 hours.

The oil concentrations (tonne. $\mathrm{km}^{-2}$ ) of the T3 spill scenario in March (a-d) and July (e-h) are presented in Fig. 5 for $12 \mathrm{~h}(\mathrm{a}, \mathrm{e}), 24 \mathrm{~h}(\mathrm{~b}, \mathrm{f}), 36 \mathrm{~h}(\mathrm{c}, \mathrm{g})$ and $48(\mathrm{~d}, \mathrm{~h})$ hours after the spill, on the water $(c, h)$ and the coast (d). A critical situation is presented in Fig. 6, which represents the concentration of oil (tonne. $\mathrm{km}^{-2}$ ) that reached FNA coast in March 48 hours after the release. In the T3 scenario the percentage of oil evaporated in the first 30 minutes was $1.97 \%$ in March and $2.54 \%$ in July with the maximum evaporation volume reached after 1.5 hours from the start of the spill. The percentage of final oil on the surface was $73.0 \%$ and $75 \%$ and the dispersed percentage was $0.3 \%$ and $0.6 \%$ in March and July, respectively. Similarly to scenarios T1 and T2, the viscosity of the emulsion for T3 was higher for the month of July $\left(79.6 \mathrm{~m}^{2} \mathrm{~s}^{-1}\right)$ than for the month of March (58.7 $\mathrm{m}^{2} \mathrm{~s}^{-1}$ ), with the stabilization of the mousse after 28 hours at $2664 \mathrm{~m}^{2} \mathrm{~s}^{-1}$ in July and final viscosity of $2466.4 \mathrm{~m}^{2} \mathrm{~s}^{-1}$ in March without stabilization. In the March T3 scenario, the spill reached the shore after 45 hours with a volume of $2.2 \%$ of the total spill adhered to the shore, which corresponds to approximately 1350 tonnes of oil, mostly on Rata Islet. With regard to the July scenario, the spill reached near to FNA coast 48 hours after the release. 

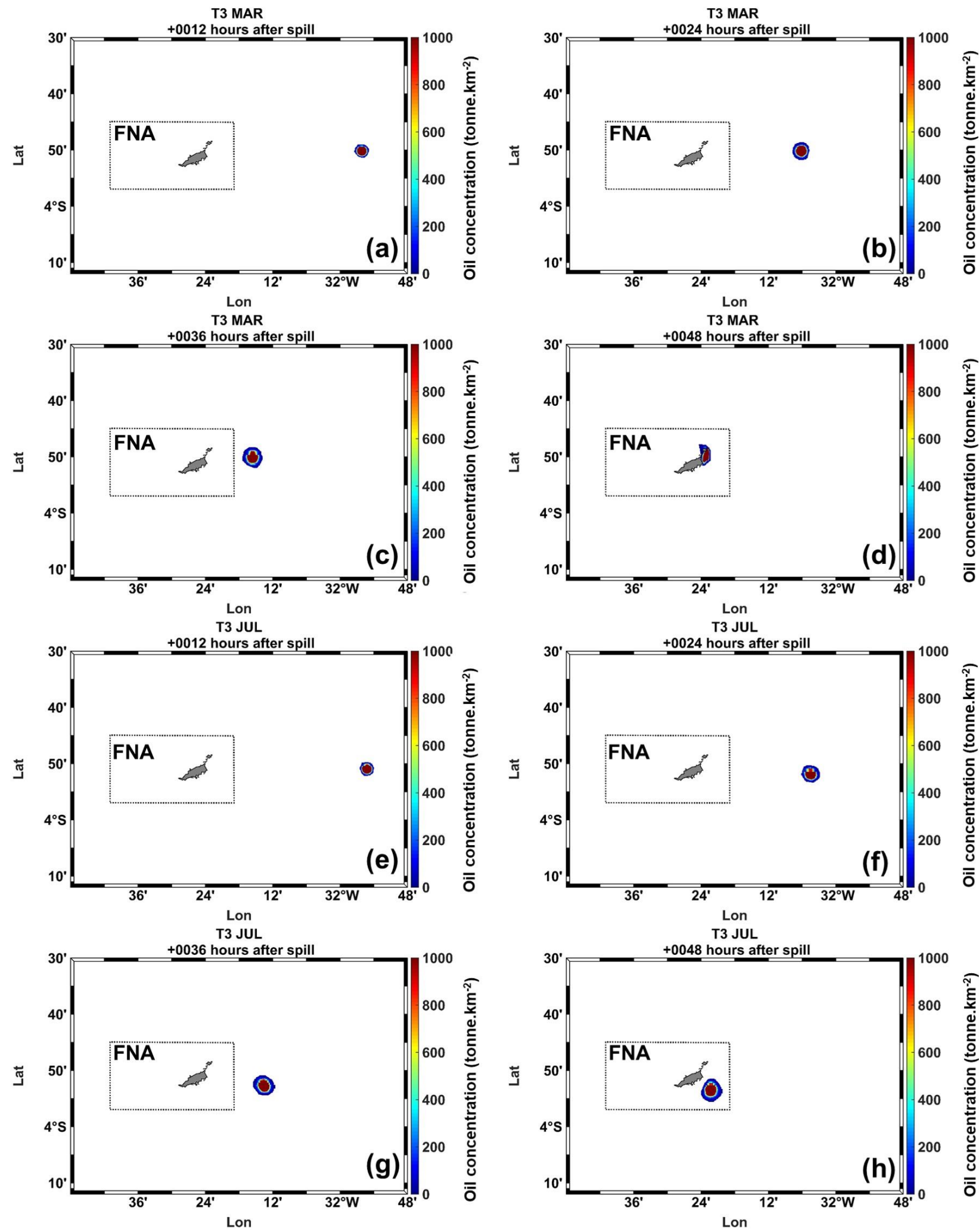

Figure 5. Scenario T3 - March: Oil concentration on the water (tonne. $\mathrm{km}^{2}$ ) after (a) 12 hours, (b) 24 hours, (c) 36 hours, (d) 48 hours; Scenario T3 - July: Oil concentration on the water (ton. km²) after (e) 12 hours, (f) 24 hours, (g) 36 hours and (h) 48 hours. 


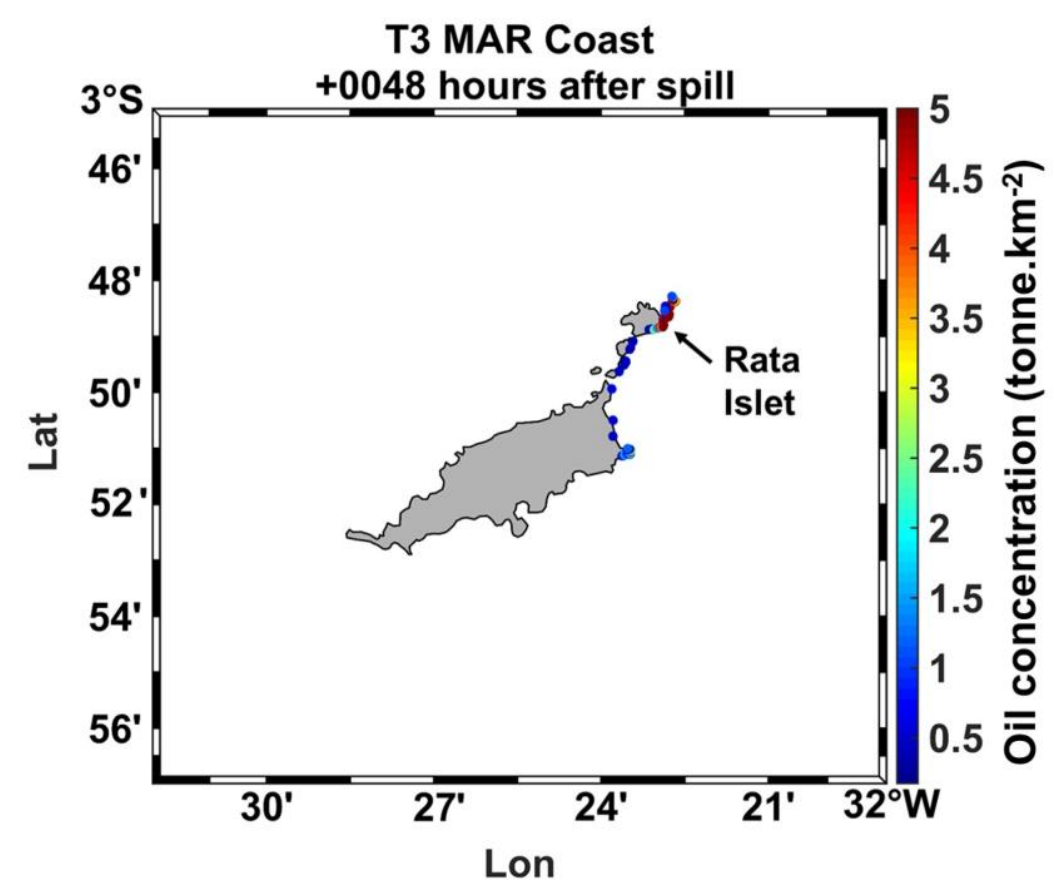

Figure 6. Scenario T3 - March: Oil concentration on the water (tonne. $\mathrm{km}^{2}$ ) on FNA shore after 48 hours.

\section{DISCUSSION}

Based on the results of the simulations, the formation of a stable and high viscosity emulsion inhibited oil spreading but only after 19 hours for all the scenarios. The formation of emulsions a few kilometers from a spill has already been observed in previous tropical regions, and may be associated with oxidation by sunlight or microbial activity (Atwood and Ferguson, 1982) and/or wave and wind dynamics (Reed et al., 1994). In our case, the rapid emulsification is primarily due to the wind shear that provides energy for emulsification, but not enough to disperse it again. Besides the inhibition of processes that tend to disperse the remaining oil (Lee et al., 2015), the emulsification should also decrease the evaporation and spreading rates (NRC, 2003). However, in our scenarios the evaporation percentage reached its maximum (defined according to the type of oil) 1 to 1.5 hours after the start of the spill, before the formation of the stable emulsion. The rate of evaporation in the MEDSLIK-II is determined by the physicochemical properties of the oil, spreading rate, seawater temperature, and winds (De Dominicis et al., 2013a). In the case of lighter oils, the evaporation would help reduce the impact of the spill reaching the coast (Lee et al., 2015). Heavier oils, with higher contents of asphaltenes, wax, and other components, would form more stable mousses and the evaporative rate would no longer be as important (Bobra et al., 1992). For the intermediary oil type analyzed, the evaporative loss was not as significant as the volume that reached FNA in the T3 scenario i.e., evaporation has not reduced the risk to the region. Additionally, the increase in density due to evaporation and emulsification was not sufficient to increase the percentage of particles sinking through the water column to the ocean bottom. This indicates that the advective processes prevail over buoyancy effects. 
The combination of the current and wind direction presents a particular situation for the FNA region. The westward current and the predominant southeast wind (bulk transport to the west) intensifies the transportation of the spill towards the archipelago. While the wind influenced on the observed direction of the plume, especially in the highest wind regime (July), the current directionality dominated the flow. In real spills, there is some variation regarding the plume directionality in relation to the wind direction that can be caused by inertial motions and the formation of Langmuir cells (Atwood and Ferguson, 1982; Lehr, 2010). As these processes are highly random, they have not yet been incorporated into oil spill models in a computationally feasible way (Spaulding, 2017) but should be considered as possible sources of errors for oil spill models.

In the critical situation associated to the T3 scenario, the combination of geophysical and biophysical processes brought high oil concentrations (up to 100 tonnes. $\mathrm{km}^{-2}$ ) on the northeastern FNA after 48 hours from accidental oil release. The region most affected by the spill comprises the islet of Rata during March and the Sueste Bay and adjacent regions during July. Both are sensitive regions, the first comprehending nurseries for seabirds such as Brown Booby (Sula leucogaster) and Red-billed Tropicbird (Phaethon aethereus) (Sharpe, 1890) and the second that houses the only mangrove on the island (Santana et al., 2016). Considering the set of marine species in FNA, six that inhabit the APA/FN and sixteen the PARNAMAR/FN are already included on the List of Threatened Species protected in these Conservation Units (ICMBIO, 2017). Additionally, ten of the 196 known reef fish species are endemic (Sampaio et al., 2006). The list of marine organism includes many that are considered important for the ecological tourism, such as sharks and flagship species as the green turtle (Chelonia mydas) and the spinner dolphin (Stenella longirostris) (ICMBIO, 2017). Any damage for these populations, aside from ecosystem damage, implicate in loss for the ecological tourism that allows the maintenance of both the environmental protection area and the marine park. The position of the spill at 48 hours within the archipelago area in $\mathrm{T} 1$ July scenario also implicates risks for the region.

In all scenarios evaluated, the advection process had a greater significance than the weathering processes for the behavior of the spill. In summary, in particular in the FNA, the predominance of advective forces tend to counteract the oil degradation processes (increases emulsification, reduce spreading and dispersion) and shorten the time window for possible mitigation actions. Once the oil reaches the island, the same heterogeneity of the habitats that provides the high biodiversity (Serafini and França, 2010) can become a challenge for the decision makers. The spill response options depend on many factors, including sediment type and vegetation affected, such as mangrove that are considered highly sensitive zones where oil tends to persist for a long time (Burns et al., 1993; Lewis, 1983).

Most of the responses for the spill, aside for containment before the plume reaches the shore, may cause more damage than the oil spill itself, as in the case of the attempt to clean the 
sediment and/or burn the oil (Lee et al., 2015). Considering the preservation of the FNA, the response to the oil spill needs to be fast, preferably before mousse stabilization to avoid the use of chemical dispersants. The response should be mechanical due to the little knowledge we have about the consequences of using chemical or biological alternatives in the region (Lee et al., 2015). The trends of higher initial evaporation rates, stronger intensification of the dispersion and emulsification processes were identified during July, when compared to March. In July, this time window is smaller due to the emulsification - highly variable, between 19 and 31 hours for the stabilization - while in March is smaller due to the faster advection (T3 scenarios). Additionally, in T1 and T2 scenarios there was a deviation of the spill to the north larger than to the south of FNA. This characteristic should be reassessed when the possibility of serving as a natural protection for the island against possible spills in the latitudes investigated. Therefore, and considering all that has been seen, preventive measures are the most viable options in the face of possible spills.

Although the Fernando de Noronha Archipelago is classified as an Ecologically Sensitive Area, in accordance with the parameters established for the designation of a particularly sensitive area (PSSA/MARPOL-IMO, 2006), the restrictions on vessel traffic around the major island are minimal. The main legislation is focused on traffic at the west of the island and port restrictions. Regarding international vessel traffic, the Brazilian marine law (DPC-MB/NORMAM 08, 2013) recognizes the right of innocent passage of vessels of any nationality in the Brazilian territorial sea.

The risk of the spill reaching the inner area of the FNA is primarily linked to the range of latitude of the starting point of the spill. Whereas the timing for the same initial site results in different coastal regions reached by the spill. We propose the delimitation of a region between $3^{\circ} 41.9^{\prime} \mathrm{S}$ and $03^{\circ} 57^{\prime} \mathrm{S}$ and $\sim 62 \mathrm{~km}$ perpendicular from the eastern limit of the FNA, restrictive to tanker traffic. The region limits correspond southern limit of the FNA, the latitude of T1 and the distance of T3 spill site in relation to the FNA, respectively (Fig. 7). In this way, in the event of a spill, the decision makers would have the average 48 hours response window to take the necessary actions and prevent the damage from reaching the archipelago. Increasing the distance from the eastern boundary of this restrictive region would implicate a larger time window for oil spill response. Another recommendation is the reinforcement of traffic outside the western boundary of the FNA, since the current and the wind would carry the oil away from the region. In addition, we emphasize the need for incorporation of sensitivity and vulnerability analysis into risk assessment to the oil spill modeling. This type of integrated evaluation is a fundamental tool in the oil spill response plan (Gundlach and Hayes, 1978; Zacharias and Gregr, 2005), even more so for the archipelago considering its distance from the main land and the lack of infrastructure. 


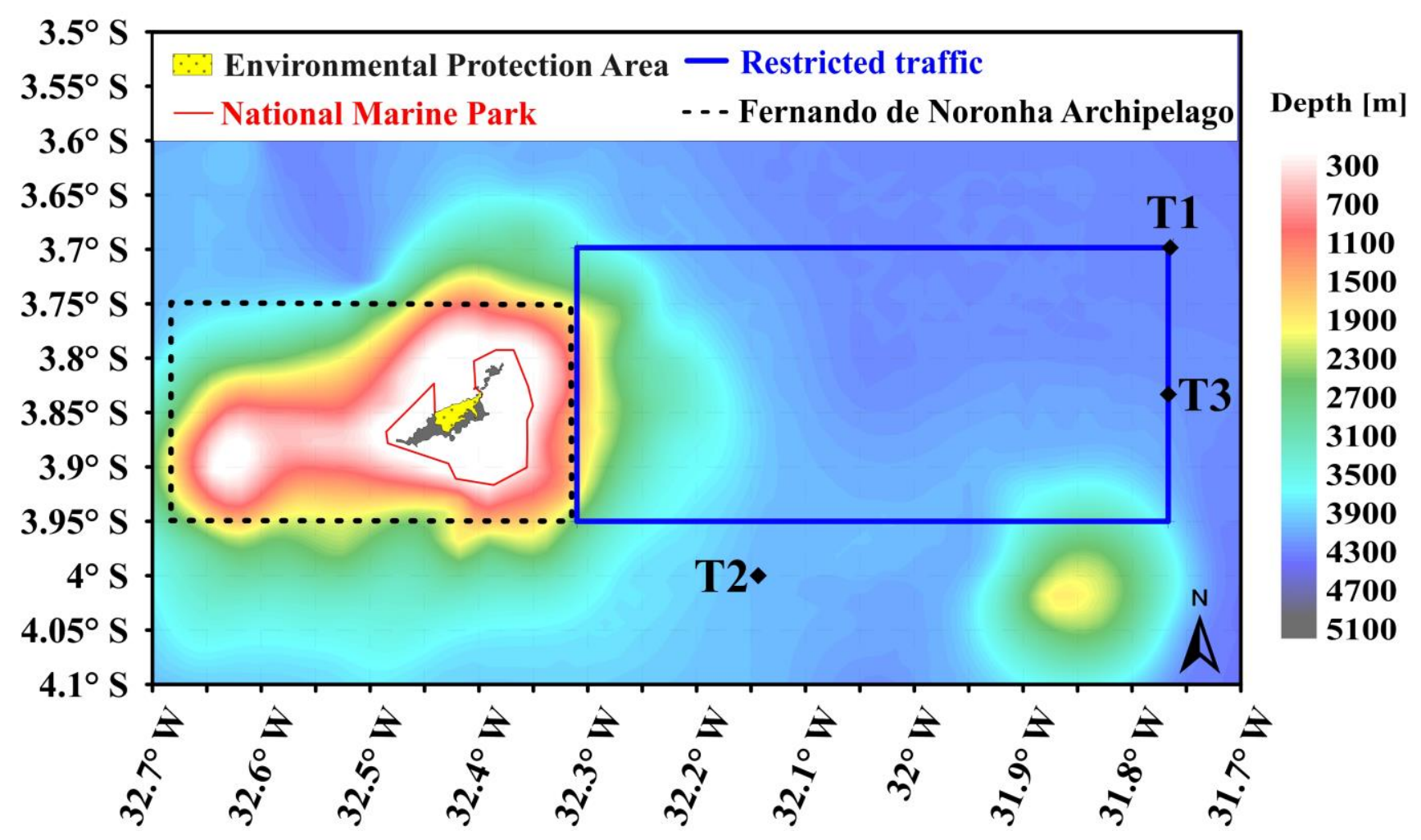

Figure 7. Region of restricted traffic for tankers with limits between $03^{\circ} 57^{\prime} \mathrm{S}$ and $3^{\circ} 41.9^{\prime} \mathrm{S}$ and $32^{\circ} 19^{\prime} \mathrm{W}$ and $31^{\circ} 46.0^{\prime} \mathrm{W}$ (blue filled line). The area delimited in red corresponds to the Marine National Park (PARNAMAR) and in yellow dotted to the Environmental Protection Area (APA) of Fernando de Noronha. T1, T2 and T3 indicate the coordinates of three release oil spill scenarios considered in simulation. The Fernando de Noronha Archipelago (FNA) correspond to the black dashed line.

\section{CONCLUSION}

This work provided a methodology to apply a model adapted to the Southwest Atlantic dynamics that can be used as a tool for mitigation and for formulating risk management forecast plans for regions of interest. The coupled ROMS and MEDSLIK-II models allows the use of current, wind and sea surface temperature results to calculate oil transport and concentration, computing weathering processes, from a surface oil spill.

The weathering processes that would tend to reduce the risk in the tropical region of the FNA happen in a slower pace than the advective forcing. In turn, the high speed of oil transport reduces the time window for possible mitigation actions, which makes preventive actions the most viable options in the face of possible spills. If we consider the potential increase in extreme events with climate change and the Oil tankers crossing at less than $50 \mathrm{~km}$ from outside to the east of FNA, we must consider the possibility of increased risk of oil spills to this region. According to the results of the simulation, the place where the oil reached the coast is part of the Fernando de Noronha Marine National Park area. The scenarios evaluated highlighted the need for a reassessment of the risks to the region and the consequent delimitation of a critical restrictive 
region for the traffic of large ships. In addition, once the model is implemented and functional, the next steps consist of running new simulations for Fernando de Noronha and other sensitive regions of the Southwest Atlantic considering different types and volumes of oil ranging from transoceanic cargos fuel capacity to small and large tankers crude oil capacity. Together with vulnerability and sensitivity to oil spill evaluations, this covers a large amount of scenarios that should be used as tools for mitigation plans.

The sustainable management of coastal zones should benefit from the implementation of systems with accurate real-time ocean observations that enable the prediction of oil trajectories in the period after the initial spill. The results of the model spill scenarios that consider the weathering allows greater effectiveness in accident prevention and containment in the event of a real accident, with a good margin of accuracy and precision. Thus, the methodology presented herein can be used to support policy makers decisions and the implementation of legal mitigating measures in those oceanic ecosystems.

\section{ACKNOWLEDGMENTS}

We acknowledge the Programa de Recursos Humanos-47 of the Agência Nacional de Petróleo (ANP/PRH-47) for providing student scholarship to S.Q. and M.A. thanks the INCT AmbTropic - National Institute on Science and Technology for Tropical Marine Environments, CNPq/FABESB (565054/2010-4 and 8936/2011). This work is a contribution to the LMI TAPIOCA.

\section{APPENDIX A. SUPPLEMENTARY MATERIAL}

The Supplementary Material for this article can be found online at https://periodicos.ufpe.br/revistas/index.php/TROPICALOCEANOGRAPHY/index

\section{REFERENCES}

Agência Nacional do Petróleo (ANP) (2017), Boletim Mensal da Produção de Petróleo e Gás Natural. In: http://www.anp.gov.br/publicacoes/boletins-anp/2395-boletim\%20mensalda-producao-de-petroleo-e-gas-natural (access in 6 October 2017).

Atwood, D. and Ferguson, R. (1982), An Example Study of the Weathering of Spilled Petroleum in a Tropical Marine Environment: IXTOC-1, Bulletin of Marine Science, Vol. 32, pp. 1-13, in: https://www.ingentaconnect.com/content/umrsmas/bullmar/1982/00000032/00000001/art 00001 (acess in 24 November 2019).

Becker, H. (2001), Hidrologia dos bancos e ilhas oceânicas do nordeste brasileiro. Uma contribuição ao Programa REVIZEE, Departamento de Oceanografia Física, Universidade Federal de São Carlos, São Carlos, São Paulo, p. 158. 
Bobra, M., Fingas, M. and Tennyson, E. (1992), When oil spills emulsify, Chemtech, Vol. 22, pp. 236-241, in: https://www.bsee.gov/sites/bsee.gov/files/osrr-oil-spill-responseresearch//120av.pdf (acess in 24 November 2019).

BRASIL, Decreto n. 92.755 de 05 de junho de 1986 (1986), Declara Área de Proteção Ambiental o território federal de Fernando de Noronha, o Atol das Rocas e os Penedos de São Pedro e São Paulo, e dá outras providências. Diário Oficial da União, Poder Executivo, Brasília, DF, 06 jun. 1986, p. 8218, In: https://www.planalto.gov.br/ccivil_03/decreto/19801989/1985-1987/d92755.htm (access in 10 November 2017).

BRASIL, Decreto n. 96.693 de 14 de setembro de 1988 (1989), Cria o Parque Nacional Marinho de Fernando de Noronha e dá outras providências, Diário Oficial da União, Poder Executivo, Brasília, DF, 15 nov. 1988, p. 17698, in: https://www.planalto.gov.br/ccivil_03/decreto/1980-1989/d96693.htm (access in 10 November 2017).

Burns, K.A., Garrity, S.D. and Levings, S.C. (1993), How many years until mangrove ecosystems recover from catastrophic oil spills?, Marine Pollution Bulletin, Vol. 26, n. 5, pp. 239-248, DOI: https://doi.org/10.1016/0025-326X(93)90062-O.

Casey, K.S. and Cornillon, P.A. (1999), Comparison of satellite and in situ-based sea surface temperature climatologies, Journal of Climate, Vol. 12, n. 6, pp. 1848-1863, DOI: https://doi.org/10.1175/1520-0442(1999)012<1848:ACOSAI>2.0.CO;2.

Chaves, T.B.C., Mafalda Jr, P., Santos, C., Souza, C.S., Moura, G., Sampaio, J., Melo, G., Passavante, J.Z.O. and Feitosa, F.A.N. (2006), Biomassa planctônica e hidrografia na Zona Econômica Exclusiva do Nordeste do Brasil, Tropical Oceanography, Vol. 34, n. 1, pp. 1-45, DOI: https://doi.org/10.5914/tropocean.v34i1.5078.

Cintra, M.M., Lentini, C.A., Servain, J., Araujo, M. and Marone, E. (2015), Physical processes that drive the seasonal evolution of the Southwestern Tropical Atlantic Warm Pool, Dynamics of Atmospheres and Oceans, Vol. 72, pp. 1-11, DOI: https://doi.org/10.1016/j.dynatmoce.2015.08.001.

Cruz, A.M. and Krausmann, E. (2013), Vulnerability of the oil and gas sector to climate change and extreme weather events, Climatic Change, Vol. 121, n. 1, pp. 41-53, 2013, DOI: https://doi.org/10.1007/s10584-013-0891-4.

Da Silva, A., Young, C. and Levitus S. (1994), Algorithms and procedures, Vol. 1, Atlas of Surface Marine Data, NOAA Atlas NESDIS, Vol. 6, p. 74.

De Dominicis, M.D., Pinardi, N., Zodiatis, G. and Lardner, R. (2013a), Medslik-II, a Lagrangian marine surface oil spill model for short-term forecasting - Part 1: Theory. Geoscientific Model Development, Vol. 6, pp. 1851-1869, DOI: https://doi.org/10.5194/gmd-6-1851-2013.

De Dominicis, M.D., Pinardi, N., Zodiatis, G. and Archetti, R. (2013b), MEDSLIK-II, a Lagrangian marine surface oil spill model for short-term forecasting - Part 2: Numerical simulations and 
validations, Geoscientific Model Development, Vol. 6, pp. 1871-1888, DOI: https://doi.org/10.5194/gmd-6-1871-2013.

de Souza, C.S., da Luz, J.A.G., Macedo, S., Montes, M.D.J.F. and Mafalda, P. (2013), Chlorophyll $a$ and nutrient distribution around seamounts and islands of the tropical south-western Atlantic, Marine and Freshwater Research, Vol. 64, n. 2, pp. 168-184, DOI: https://doi.org/10.1071/MF12075.

Do Sul, J.A.I., Spengler, A. and Costa, M.F. (2009), Here, there and everywhere. Small plastic fragments and pellets on beaches of Fernando de Noronha (Equatorial Western Atlantic), Marine Pollution Bulletin, Vol. 58, n. 8, pp. 1236-1238, DOI: https://doi.org/10.1016/j.marpolbul.2009.05.004.

DPC-MB/NORMAM 08 (2013), Diretoria de Portos e Costas - Marinha de Brasil, NORMAM 08/DPC - Tráfego e Permanência de Embarcações em Águas Jurisdicionais Brasileiras, in: https://www.dpc.mar.mil.br/sites/default/files/normam08.pdf (access in 02 December 2017).

Ekau, W. and Knoppers, B. (1999), An introduction to the pelagic system of the North-East and East Brazilian shelf, Archive of Fishery and Marine Research, Vol. 47, n. 2/3, pp. 113-132, in:https://www.researchgate.net/profile/Werner_Ekau/publication/279695392_An_introdu ction_to_the_pelagic_system_of_the_North-

East_and_East_Brazilian_shelf/links/573470d608aea45ee83ab8d5.pdf (acess in: 24 November 2017).

Gillespie, R.G. (2007), Oceanic islands: models of diversity, Encyclopedia of Biodiversity, pp. 113. DOI: https://doi.org/10.1016/b978-0-12-384719-5.00231-8.

Gove, J.M., McManus, M.A., Neuheimer, A.B., Polovina, J.J., Drazen, J.C., Smith, C.R., Merrifield, M.A., Friedlander, A.M., Ehses, J.S., Young, C.W., Dillon, A.K. and Williams, G.J. (2016), Near-island biological hotspots in barren ocean basins. Nature communications, Vol. 7, p. 10581, DOI: https://doi.org/10.1038/ncomms10581.

Gundlach, E.R. and Hayes, M.O. (1978), Vulnerability of coastal environments to oil spill impacts, Marine Technology Society Journal, Vol. 12, n. 4, pp. 18-27, in: https://www.oilspill-info.com/Publications/1978_MTS_Vulnerability_ESI.pdf (acess in 24 November 2017).

Hazin, F.H. (1993), Fisheries-oceanographical study on tunas, billfishes and sharks in the southwestern equatorial Atlantic Ocean. University of Fisheries, Tokyo, 286.

Hounsou-Gbo, G.A., Araujo, M., Bourlès, B., Veleda, D. and Servain, J. (2015), Tropical Atlantic contributions to strong rainfall variability along the Northeast Brazilian coast, Advances in Meteorology, Vol. 2015, Article ID 902084, p. 13, DOI: http://dx.doi.org/10.1155/2015/902084.

IBAMA (2005), Instituto do Meio Ambiente. Plano de Manejo da APA Fernando de Noronha - Rocas - São Pedro e São Paulo: Resumo Executivo, Instituto Brasileiro do Meio Ambiente e dos Recursos Naturais Renováveis - $\quad$ IBAMA, in: 
http://www.icmbio.gov.br/portal/images/stories/imgs-unidadescoservacao/Resumo\%20Executivo_f.pdf (access in 9 September 2017).

ICMBIO (2017), Instituto Chico Mendes de Conservação da Biodiversidade - Busca - Unidades de Conservação, in: http://www.icmbio.gov.br/portal/unidades-de-conservacao (access in 10 September 2017).

Large, W.G., McWilliams, J.C. and Doney, S.C. (1994), Oceanic vertical mixing: A review and a model with a nonlocal boundary layer parameterization, Reviews of Geophysics, Vol. 32, n. 4, pp. 363-403, DOI: https://doi.org/10.1029/94RG01872.

Lee, K., Boufadel, M., Chen, B., Foght, J., Hodson, P., Swanson, S. and Venosa, A. (2015), The Behaviour and Environmental Impacts of Crude Oil Released into Aqueous Environments, The Royal Society of Canada, Ottawa, 489p.

Lehr, W.J. (2010), Review of modeling procedures for oil spill weathering behavior, Advances in Ecological Sciences, vol. 9, pp. 51-90, in: http://citeseerx.ist.psu.edu/viewdoc/download?doi=10.1.1.226.484\&rep=rep1\&type=pdf (acess in 24 September 2019).

Leitão, S., Gusmao, L.M.D., Silva, T.D.E., Nascimento-Vieira, D.A. and Silva, A.P. (1999), Mesozooplankton biomass and diversity in coastal and oceanic waters off North-Eastern Brazil, Archive of Fishery and Marine Research, Vol. 47, n. 2, pp. 153-165, ISSN: 09441921.

Lemarié, F., Debreu, L., Shchepetkin, A.F. and McWilliams, J.C. (2012), On the stability and accuracy of the harmonic and biharmonic isoneutral mixing operators in ocean models, Ocean Modelling, Vol. 52, pp. 9-35, DOI: https://doi.org/10.1016/j.ocemod.2012.04.007.

Lewis, R.R. (1983), Impact of oil spills on mangrove forests, Biology and Ecology of Mangroves, pp. 171-183, Springer, DOI: https://doi.org/10.1007/978-94-017-0914-9_19.

Lumpkin, R. and Garzoli, S.L. (2005), Near-surface circulation in the tropical Atlantic Ocean, Deep Sea Research Part I: Oceanographic Research Papers, Vol. 52, n. 3, pp. 495-518, DOI: https://doi.org/10.1016/j.dsr.2004.09.001.

Lumpkin, R. and Johnson, G.C. (2013), Global ocean surface velocities from drifters: Mean, variance, El Niño-Southern Oscillation response, and seasonal cycle, Journal of Geophysical Research: Oceans, Vol. 118, n. 6, pp. 2992-3006, DOI: https://doi.org/10.1002/jgrc.20210.

Marchesiello, P., Debreu, L. and Couvelard, X. (2009), Spurious diapycnal mixing in terrainfollowing coordinate models: The problem and a solution, Ocean Modelling, Vol. 26, n. 3, pp. 156-169, DOI: https://doi.org/10.1016/j.ocemod.2008.09.004.

MARINETRAFFIC (2017), MarineTraffic: Global Ship Tracking Intelligence | AIS Marine Traffic, in: http://www.marinetraffic.com/ (access in $1^{\text {st }}$ October 2017).

Marta-Almeida, M., Ruiz-Villarreal, M., Pereira, J., Otero, P., Cirano, M., Zhang, X. and Hetland, R.D. (2013), Efficient tools for marine operational forecast and oil spill tracking, Marine 
Pollution Bulletin, Vol. 71, n. 1, pp. 139-151, DOI: https://doi.org/10.1016/j.marpolbul.2013.03.022.

Molinari, R.L. (1982), Observations of eastward currents in the tropical South Atlantic Ocean: 1978-1980, Journal of Geophysical Research: Oceans, Vol. 87, pp. 9707-9714, DOI: https://doi.org/10.1029/JC087iC12p09707.

National Research Council (NRC) (2003), Oil in the Sea III: Inputs, Fates, and Effects, Washington, DC: The National Academies Press, 265 p.

Nordvik, A.B. (1999), Time window-of-opportunity strategies for oil spill planning and response, Pure and Applied Chemistry, Vol. 71, pp. 5-16, in: http://citeseerx.ist.psu.edu/viewdoc/download?doi=10.1.1.487.7854\&rep=rep1\&type=pdf (acess in 24 September 2019).

Oudot, J. and Dutrieux, E. (1989), Hydrocarbon weathering and biodegradation in a tropical estuarine ecosystem, Marine Environmental Research, Vol. 27, n. 3-4 pp. 195-213, DOI: https://doi.org/10.1016/0141-1136(89)90024-X.

Page, D.S., Mayo, D.W., Cooley, J.F., Sorenson, E., Gilfillan, E.S. and Hanson, S.A. (1979), Hydrocarbon distribution and weathering characteristics at a tropical oil spill site, International Oil Spill Conference Proceedings, Vol. 1979, n. 1, pp. 709-712, DOI: https://doi.org/10.7901/2169-3358-1979-1-709.

Penven, P., Marchesiello, P., Debreu, L. and Lefèvre, J. (2008), Software tools for pre-and postprocessing of oceanic regional simulations, Environmental Modelling \& Software, Vol. 23, n. 5, pp. 660-662, DOI: https://doi.org/10.1016/j.envsoft.2007.07.004.

PSSA/MARPOL-IMO (2006), Revised Guidelines For The Identification And Designation of Particularly Sensitive Sea Areas, International Maritime Organization - IMO, in: http://www.imo.org/en/OurWork/Environment/PSSAs/Documents/A24-Res.982.pdf (access in Sep. 2019).

Reed, M., Turner, C. and Odulo, A. (1994), The role of wind and emulsification in modelling oil spill and surface drifter trajectories, Spill Science \& Technology Bulletin, Vol. 1, n. 2, pp.143157, DOI: https://doi.org/10.1016/1353-2561(94)90022-1.

Risien, C.M. and Chelton, D.B. (2008), A global climatology of surface wind and wind stress fields from eight years of QuikSCAT scatterometer data, Journal of Physical Oceanography, Vol. 38, n. 11, pp. 2379-2413, DOI: https://doi.org/10.1175/2008JPO3881.1.

Sampaio, C.L.S.; Carvalho-Filho, A.; Feitoza, B.M.; Ferreira, C.E.L.; Floeter, S.R.; Gasparini, J.L.; Rocha, L.A. and Sazima, I., (2006), Peixes recifais endêmicos e ameaçados das ilhas oceânicas brasileiras e do complexo recifal dos Abrolhos, pp. 215-234, in: Alves, R.J.V. and Castro, J.W.A. (Orgs.), Ilhas oceânicas brasileiras: da pesquisa ao manejo. Brasília: MMA, 298 p.

Santana, R.C.B., Silva, H.P., Carvalho, R.M.C.M.O., Frutuoso, M.N.M.A. and Brandão, S.S.F. (2016), A Importância Das Unidades De Conservação Do Arquipélago De Fernando De 
Noronha, HOLOS, Vol. 32, Ed. 7, pp. 15-31, DOI: https://doi.org/10.15628/holos.2016.4217.

Serafini, T.Z. and França, G. (2010), Ilhas oceânicas brasileiras: biodiversidade conhecida e sua relação com o histórico de uso e ocupação humana, Revista de Gestão Costeira Integrada/Journal of Integrated Coastal Zone Management, Vol. 10, n. 3, pp. 281-301, DOI: https://doi.org/10.5894/rgci178.

Sharpe R.B. (1890), Notes on the zoology of Fernando Noronha: Aves, Zoological Journal of the Linnean Society London, Vol. 20, pp. 477-480, in: www.nhm.ac.uk/resources/researchcuration/projects/chalcidoids/pdf_X/Kirby890.pdf (access in Sep. 2019).

Shchepetkin, A.F. and McWilliams, J.C. (2003), A method for computing horizontal pressuregradient force in an oceanic model with a nonaligned vertical coordinate, Journal of Geophysical Research, Vol. 108, n. C3, p. 3090, DOI: https://doi.org/10.1029/2001JC001047.

Shchepetkin, A.F. and McWilliams, J.C. (2005), The regional oceanic modeling system (ROMS): A split-explicit, free-surface, topography-following-coordinate oceanic model, Ocean Modelling, Vol. 9, n. 4, pp. 347-404, DOI: https://doi.org/10.1016/j.ocemod.2004.08.002.

Silva Jr, J.D. (2003), Parque Nacional Marinho de Fernando de Noronha: uso público, importância econômica e proposta de manejo, Simpósio De Áreas Protegidas: conservação no âmbito do cone sul, Vol. 2, pp. 335-342, in: https://golfinhorotador.org.br/publications/ParnamarFN_Uso-Publico_Importancia_Manejo.pdf (access in Sep. 2019).

Silva, M., Araujo, M., Servain, J. and Penven, P. (2009), Circulation and heat budget in a regional climatological simulation of the southwestern tropical Atlantic, Tropical Oceanography, Vol. 39, pp. 41-57, DOI: https://doi.org/10.5914/tropocean.v37i1-2.5156.

Song, Y. and Haidvogel, D. (1994), A Semi-implicit Ocean Circulation Model Using a Generalized Topography-Following Coordinate System, Journal of Computational Physics, Vol. 115, n. 1, pp. 228-244, DOI: https://doi.org/10.1006/jcph.1994.1189.

Soto, J.M.R. (2006), A fauna terrestre exótica do Arquipélago Fernando de Noronha - colonização natural e intervenção antrópica, in: Alves, R.J.V. and Castro, J.W.A. (Orgs.), Ilhas oceânicas brasileiras: da pesquisa ao manejo. Brasília: MMA, 298p.

Soto, J.M.R. (2009), Ações antrópicas negativas nas ilhas oceânicas brasileiras, Capítulo 13, in: Mohr, L.V.M. (2013), Ilhas Oceânicas Brasileiras - da pesquisa ao manejo, Vol. II, Brasília, MMA, 502p.

Souza, P.M.M. (2004), Distribuição e Abundância do Ictioplâncton associadas às condições oceanográficas na ZEE do Nordeste do Brasil, Dissertação (Mestrado em Ecologia e Biomonitoramento) - Salvador: Instituto de Biologia, Universidade Federal da Bahia.

Spaulding, M.L. (2017), State of the art review and future directions in oil spill modeling, Marine Pollution Bulletin, Vol. 115, n. 1-2, pp. 7-19, DOI: https://doi.org/10.1016/j.marpolbul.2017.01.001. 
Stramma, L. and Schott, F. (1999), The mean flow field of the tropical Atlantic Ocean. Deep Sea Research Part II: Topical Studies in Oceanography, Vol. 46, n. 1, pp. 279-303, DOI: https://doi.org/10.1016/S0967-0645(98)00109-X.

Tchamabi, C.C., Araujo, M., Silva, M. and Bourlès, B. (2017), A study of the Brazilian Fernando de Noronha Island and Rocas Atoll wakes in the tropical Atlantic, Ocean Modelling, Vol. 111, pp. 9-18, DOI: https://doi.org/10.1016/j.ocemod.2016.12.009.

Travassos, P., Hazin, F.H., Zagaglia, J.R., Advíncula, R. and Schober, J. (1999), Thermohaline structure around seamounts and islands off North-Eastern Brazil, Archive of Fishery and Marine Research, Vol. 47, n. 2-3, pp. 211-222, in: https://www.researchgate.net/publication/279577974_Thermohaline_structure_around_s eamounts_and_islands_off_North-Eastern_Brazil (access in Sep. 2019).

Wang, S.D., Shen, Y.M. and Zheng, Y.H. (2005), Two-dimensional numerical simulation for transport and fate of oil spills in seas, Ocean Engineering, Vol. 32, n. 13, pp. 1556-1571, DOI: https://doi.org/10.1016/j.oceaneng.2004.12.010.

Whittaker, R.J. and Fernández-Palacios, J.M. (2007), Island Biogeography: Ecology, Evolution, and Conservation, 2a ed. Great Britain: Oxford University Press, 416 p.

Zacharias, M.A. and Gregr, E.J. (2005), Sensitivity and vulnerability in marine environments: an approach to identifying vulnerable marine areas, Conservation Biology, Vol. 19, n.1, pp. 86-97, DOI: https://doi.org/10.1111/j.1523-1739.2005.00148.x. 


\section{APPENDIX A. SUPPLEMENTARY MATERIAL}

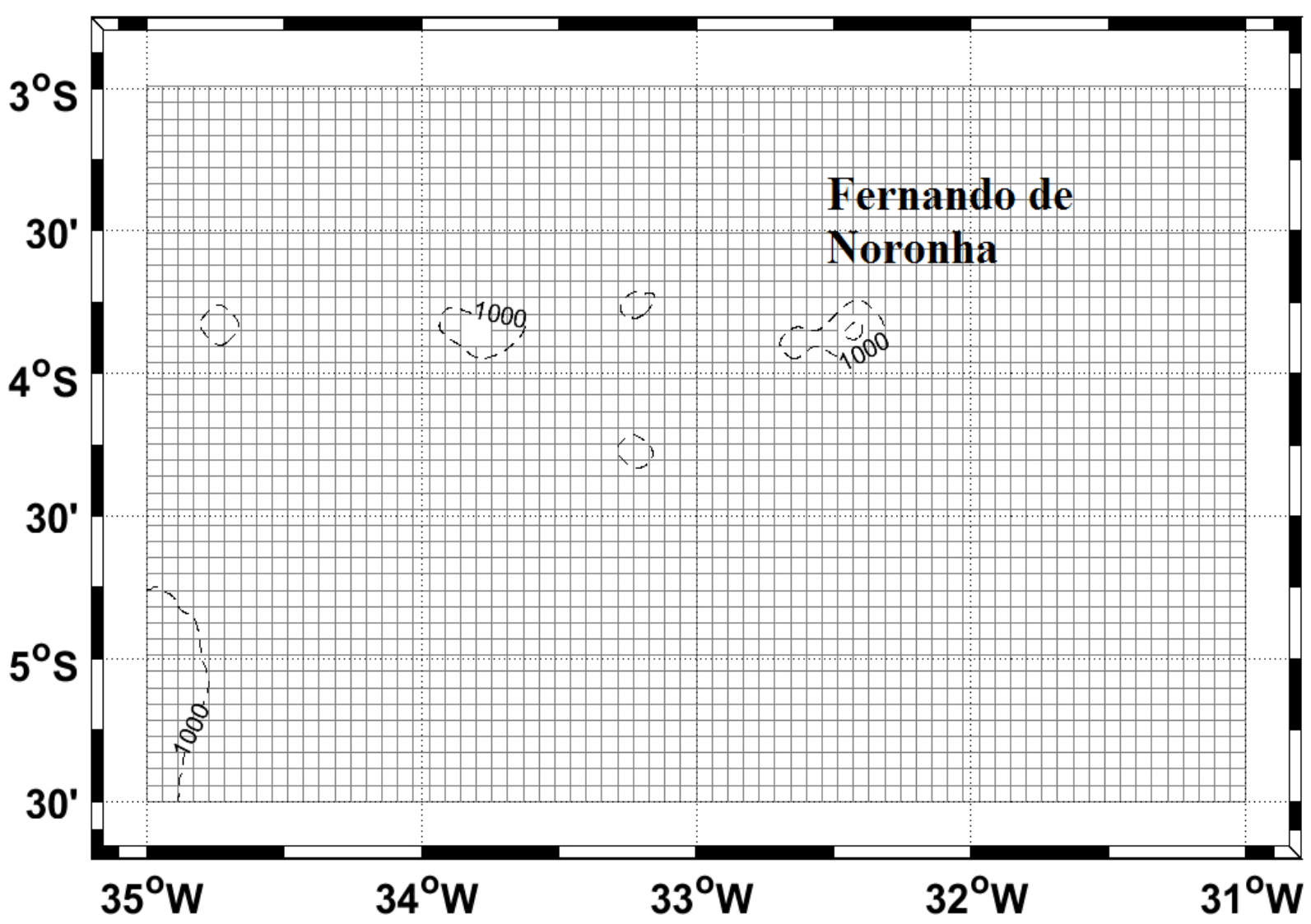

Supplemental Figure S1. Computational Domain for ROMS simulations (Lat: $3^{\circ} \mathrm{S}-5^{\circ} 30^{\prime} \mathrm{S}$; Lon: $35^{\circ} \mathrm{W}-$ $31^{\circ} \mathrm{W}$ ) around Fernando de Noronha Archipelago. 


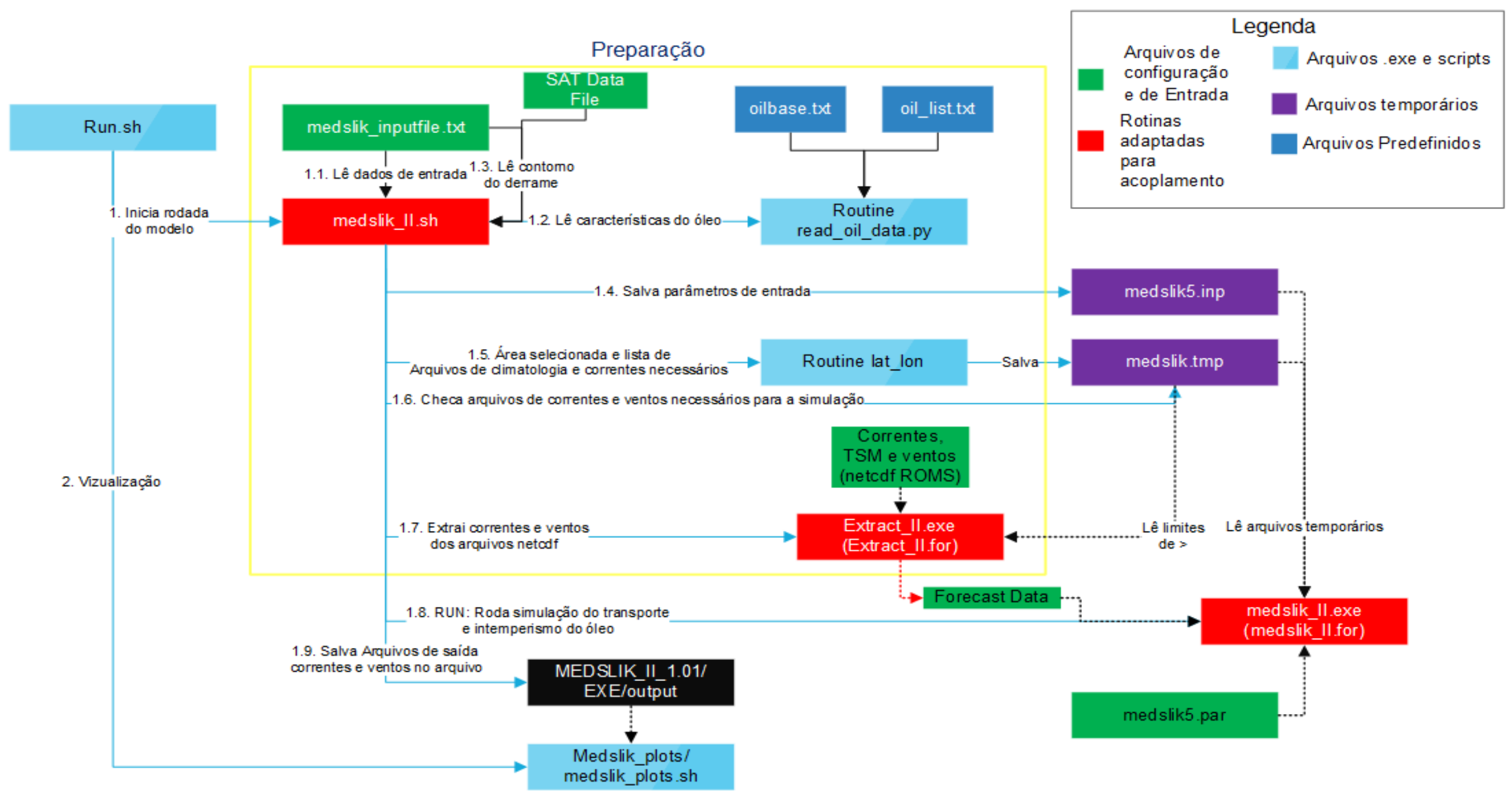

Supplemental Figure S2. MEDSLIK-II operating scheme. 
T1 MAR
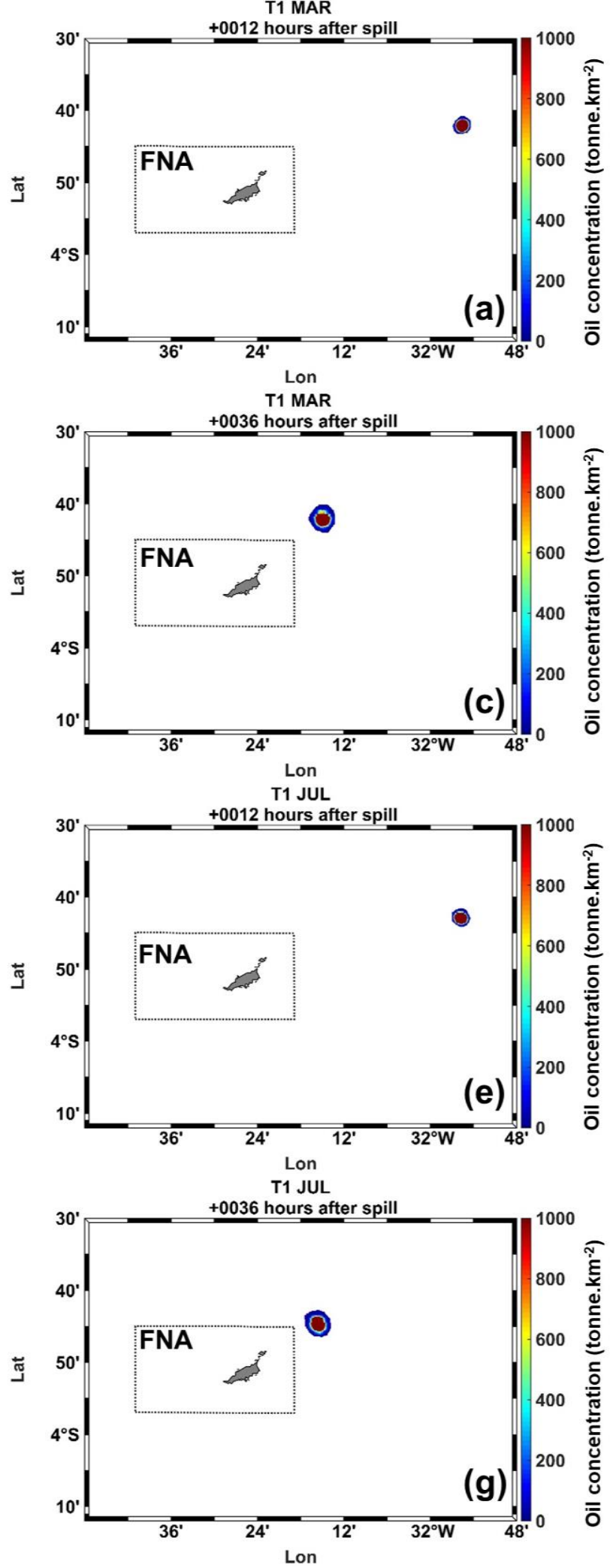

T1 MAR
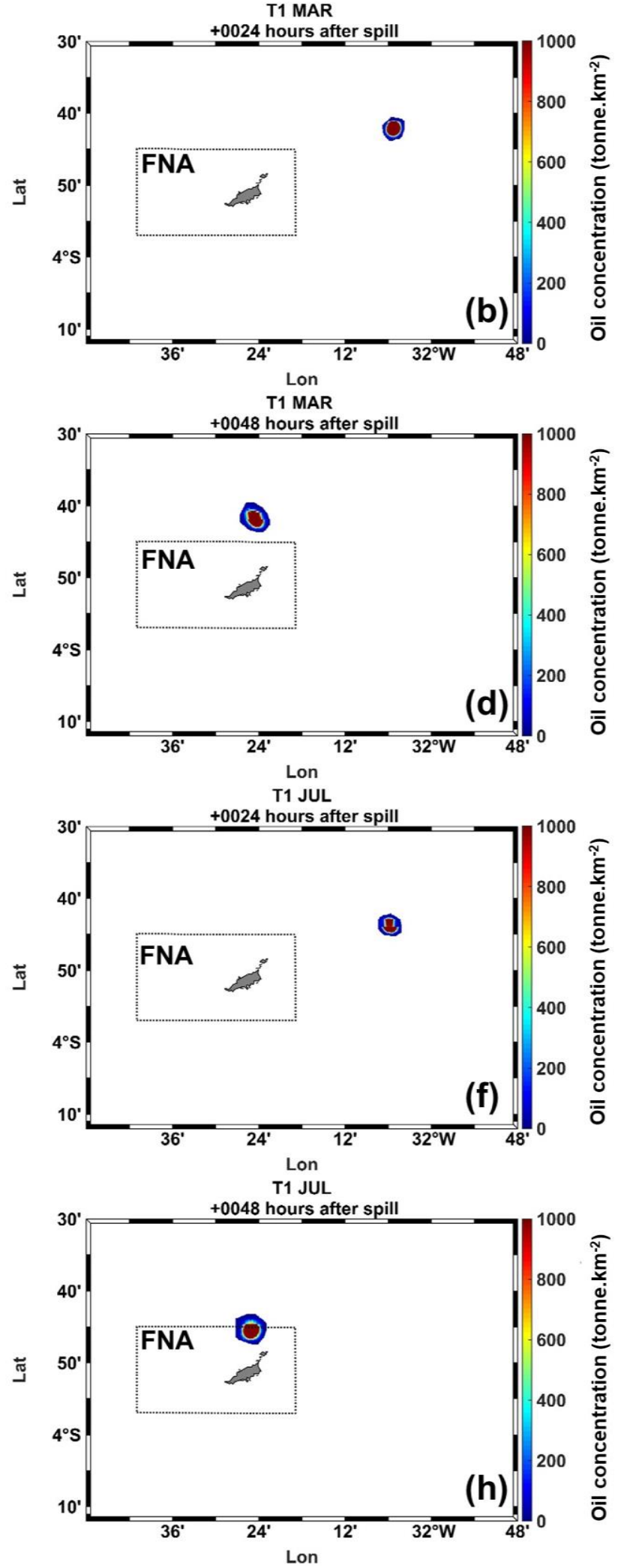

Supplemental Figure S3. Scenario T1 - March: Oil concentration on the water (tonne. $\mathrm{km}^{2}$ ) after (a) 12 hours, (b) 24 hours, (c) 36 hours, (d) 48 hours; Scenario T1 - July: Oil concentration on the water (tonnes. $\mathrm{km}^{2}$ ) after (e) 12 hours, (f) 24 hours, (g) 36 hours and (h) 48 hours. 
T2 MAR
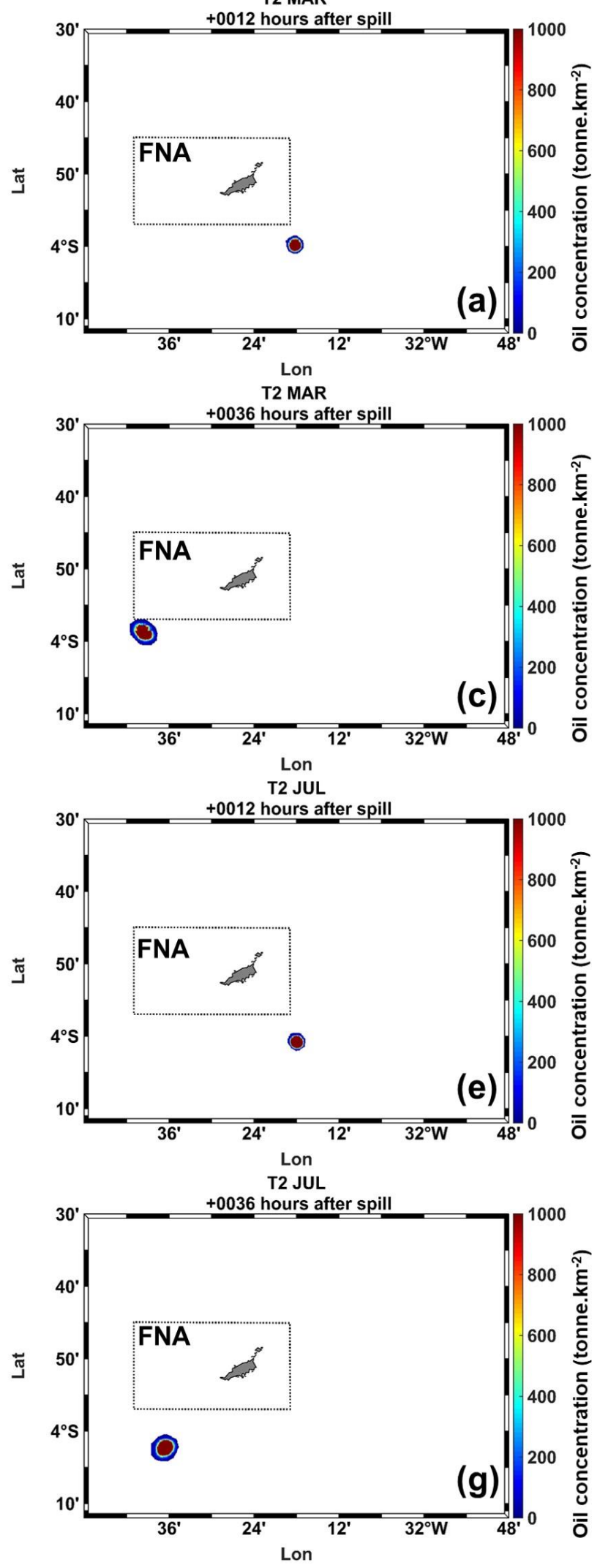

T2 MAR
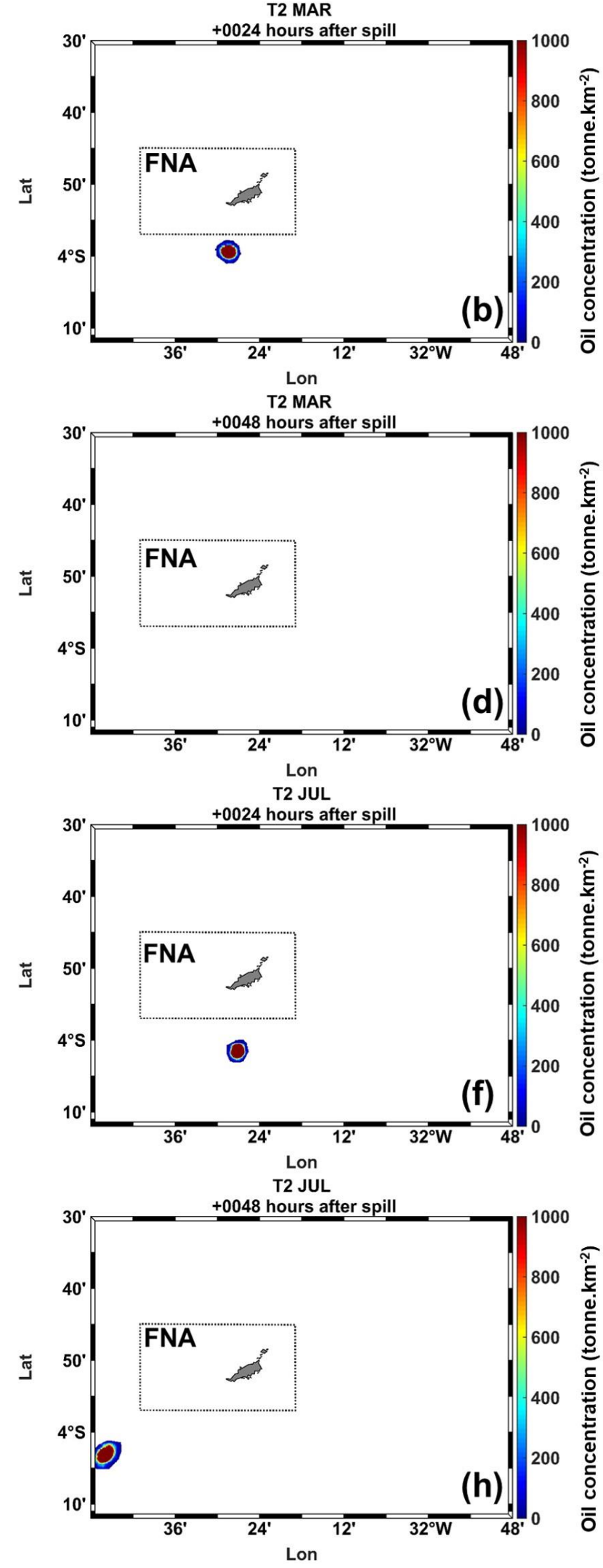

Supplemental Figure S4. Scenario T2 - March: Oil concentration on the water (tonne. $\mathrm{km}^{2}$ ) after (a) 12 hours, (b) 24 hours, (c) 36 hours, (d) 48 hours; Scenario T2 - July: Oil concentration on the water (tonnes. $\mathrm{km}^{2}$ ) after (e) 12 hours, (f) 24 hours, (g) 36 hours and (h) 48 hours. 